\title{
Physico-Chemical Factors Of Chandraprabha Wetland with Special Reference to Aquatic Biota
}

\author{
Verma, Jyoti ${ }^{1}$, Srivastava, Prateek ${ }^{2}$ and Gopesh, Anita $^{3}$ \\ ${ }^{1}$ Department of Zoology, CMP PG College, University of Allahabad, Allahabad, India \\ ${ }^{2}$ Department of Botany, CMP PG College, University of Allahabad, Allahabad, India \\ ${ }^{3}$ Department of Zoology, University of Allahabad, Allahabad, India \\ Corresponding Author: diatombuster@gmail.com
}

\section{A R T I C L E I N F O}

Received: 11 July 2018 | Accepted: 21 October 2018 | Published Online: 31 December 2018

DOI: $10.31786 / 09756272.18 .9 .2 .208$

EOI: 10.11208/essence.18.9.2.208

Article is an Open Access Publication.

This work is licensed under Attribution-Non Commercial 4.0 International

(https://creativecommons.org/licenses/by/4.0/)

CThe Authors (2018). Publishing Rights @ MANU_ICMANU \& ESSENCE—IJERC.

\section{A B S T R A C T}

River Chandraprabha is located, southwest of Varanasi in Uttar Pradesh. The present investigation was carried out to analyse the physico-chemical and biotic characteristic of reservoir (wetland) and river within Chandraprabha sanctuary. The samples were collected seasonally from April 2011 to March 2012 at Site S1 (Chandraprabha Reservoir) and Site S2 (Rajdari i.e., downstream of Chandraprabha Reservoir). The phytoplankton and zooplanktons densities varied from 584-1259 $\mathrm{u} / 1$ and 245-829 $\mathrm{u} / 1,243-889 \mathrm{u} / 1$ and 112-432 $\mathrm{u} / 1$ respectively at S1 and S2. The phytoplankton was represented by 74 and zooplankton by 13 genera in the reservoir S1 in contrast to 66 genera of phytoplankton and 13 genera of zooplankton in fluvial site S2. Phytoplankton comprised of Bacillariophyta, Chlorophyta, Cyanophyta and Euglenophyta while zooplankton comprised Cladocera, Copepoda, Rotifera and Protozoa. The densities of macroinvertebrates ranged from 231319 individuals $/ \mathrm{m} 2$ at the $\mathrm{S} 1$ while $220-352$ individuals $/ \mathrm{m} 2$ at $\mathrm{S} 2$. Major groups were Diptera, Coleoptera, Gastropoda, Odonata, Hemiptera, Trichoptera and Ephemeroptera. However, the Hemiptera was not found at S2.

\section{K E Y W O R D S}

Biota | Wetland | Phytoplankton | Zooplankton | Macroinvertebrate | Reservoir

\section{I T A T I O N}

Verma, Jyoti; Srivastava, Prateek and Gopesh, Anita (2018): Physico-Chemical Factors Of Chandraprabha Wetland with Special Reference to Aquatic Biota. ESSENCE Int. J. Env. Rehab. Conserv. IX (1): $52-59$. 


\section{Introduction}

Rivers, watersheds, and aquatic ecosystems are the biological engines of the planet. They are the basis for life and the livelihoods of local communities. Understanding, protecting, and restoring ecosystems at river basin level is essential to foster equitable human development and the welfare of all species. Dams transform landscapes and create risks of irreversible impacts. Clashes between dam proponents and critics have brought the large dams issue into focus as one of the most intensely debated issues in sustainable development [Manatunge and Priyadarshana 2006]. Wetlands are one of the richest ecosystems of earth, offering "sanctuary" to a wide diversity of plants and animals. In addition, they play other important key roles, for example provisioning and maintaining water quality for numerous living organisms. Wetlands are defined as "lands of transitional zone between terrestrial and aquatic ecosystems where the water table is usually at or near the surface or where the land is covered by shallow water" [Smith 1980; Cowardin et al., 1979]. Wetlands are often referred to as "biological supermarkets" for the extensive food chain and rich biodiversity they support [Mitsch and Gosselink 2000] and are one of the most important ecosystems, which have multiple utilities these areas, covers 58.2 million hectares in India, out of which 40.9 million hectares are under rice cultivation [Anonymous 2007]. River impoundment has led to creation of many wetlands. However, such wetlands are rarely a part of protected area (PA). It is created for the conservation of natural resources. Purpose of the study was to investigate the temporal variations in physicochemical and selected biological characteristics in the wetland and fluvial sections.

\section{Materials and Methods}

Chandraprabha was declared a wildlife sanctuary in 1957 by the Uttar Pradesh Government on account of its rich biodiversity. The Chandraprabha sanctuary, which spreads across 78 sq. kms lies on Naugarh and Vijaigarh hillocks in the Vindhya Range of dense forests in Varanasi district. It lies between north latitude 24055,38 "240 56, 48"and East longitude 830 10, 08"- 830 10, 33" (Fig 1).

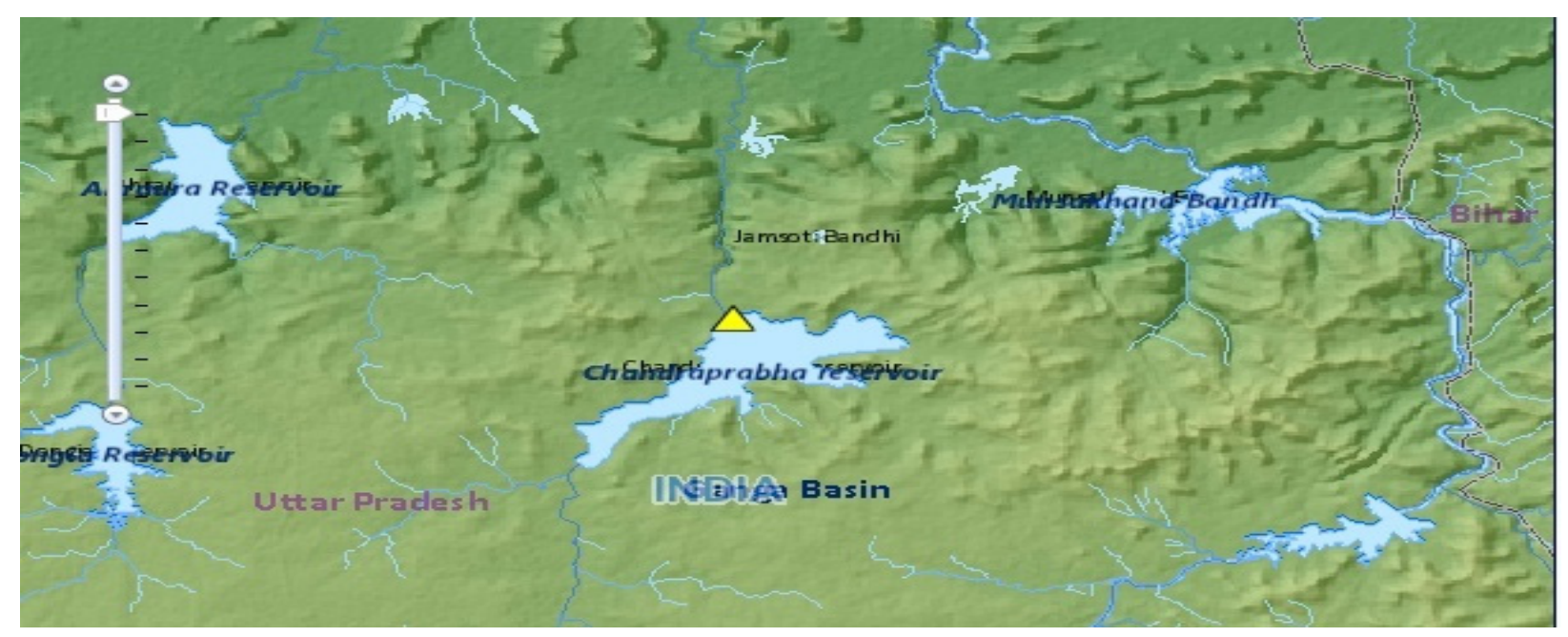

Fig. 1: Satellite image of the study area showing the Chandraprabha reservoir.

The climate is usually hot around the year with an average rainfall of $800-1000 \mathrm{~mm}$. Maximum temperatures during the long dry season in summer soars to $44^{\circ}$ Celsius while winters are usually mild. Almost $13 \%$ of the land is covered by forests, dominated by thorny species such as Zyzyphus glabarrima, Dicrostachys cinerea, Randia dumetorum and Carissa spinarum while other plant species include Bamboo, Pterocarpus, Anogeissus and Buchanania. The studies were 
carried out seasonally from April 2011 to March 2012 at two Sites S1 (Chandraprabha Reservoir) and S2 (Rajdari) within the Chandraprabha Sanctuary. Water samples for physico-chemical analysis were collected from both the sites. Temperature, conductivity, $\mathrm{pH}$, salinity and total dissolved solids were determined at the sites itself using portable Hanna meter. The chemical parameters were measured in the laboratory following the standard methods [APHA, AWWA, WPCF, WEF 1998].

The phytoplankton and zooplankton were collected by plankton net [Welch 1948] and preserved at the site. The bolting silk No. 25 (65n) was used in the net, which is attached with an iron ring of about $20 \mathrm{~cm}$ diameter in conical shape. In each collection 100 liters of surface water was collected, which was filtered through the plankton net. The filtrate thus contains plankton $10 \mathrm{ml}$ of the filtrate was preserved in $4 \%$ formalin at the spot. The quantitative and qualitative examination was done in the laboratory by the standard methods [APHA, AWWA, WPCF, WEF 1998; Needham and Needham 1975]. Before analysis each plankton sample was diluted and mixed with water to make it to $50 \mathrm{ml}, 1 \mathrm{ml}$ of this sub sample was drawn quickly with a wide mouthed pipette and poured into a sedge wick-Rafter plankton counting cell for density (indiv. m-2) and all the plankton were identified to generic levels and enumerated using standard keys [Needham and Needham PR 1975; Nwankwo 2004]. The macroinvertebrate samples were collected from $1 \mathrm{sq} f t$ area by lifting of stones. The material was sieved and preserved in 4\% formalin solution. For identification, the organisms of each taxon encountered were placed into separate Petri dish to identify the specimen by microscopic examination using dissection microscopes (binoculars with a magnification between $5 \mathrm{x}$ and 50x) and microscopes (minimum magnification 100x). Standard keys were used for the identification of macroinvertebrate samples the fauna was identified to family level [Corkum 1989; Pennak 1953; Edmondson 1959; Macan 1979] and counts were made to obtain density (indiv. $\mathrm{m}^{-2}$ ), relative abundance (as \%).

\section{Observation}

Seasonal variations are recorded in the physicochemical characteristics of the region on both the sites. However the range value of air, water temperature, $\mathrm{pH}$, salinity, silicate, nitrate and phosphate were similar for both the sites. The Dissolved Oxygen (DO), Sp. Conductivity, Total Dissolve solids (TDS) and Current Velocity (CV) varied on both the sampling sites (Table 1).

\begin{tabular}{|l|l|l|l|l|l|l|}
\hline Sites & \multicolumn{3}{l}{ S1 } & S2 & \multicolumn{2}{l|}{} \\
\hline Parameters/ Seasons & S & M & W & S & M & W \\
\hline Air Temperature $(0 \mathrm{C})$ & $31-32.8$ & $27.2-28.7$ & $21-22.3$ & $33.45-34$ & $27.5-28.9$ & $21.57-22.8$ \\
\hline Water Temperature $\left({ }^{0} \mathrm{C}\right)$ & $28.2-29.5$ & $24-26.2$ & $16-19.6$ & $29.2-29.8$ & $23.97-25$ & $16.9-17.2$ \\
\hline Ph & $8.32-8.60$ & $7.6-7.8$ & $7.56-7.85$ & $7.6-7.85$ & $7.6-7.8$ & $7.7-7.8$ \\
\hline Salinity & $0.19-0.2$ & 0.2 & $0.2-0.23$ & $0.21-0.22$ & 0.22 & $0.21-0.22$ \\
\hline Dissolved Oxygen $\left(\mathrm{mgl}^{-1}\right)$ & $3.9-6.9$ & $4.3-6.4$ & $4.8-7.1$ & $6.7-8.2$ & $6.9-7.9$ & $5.8-6.2$ \\
\hline Sp. Conductivity $\left(\mathrm{mhos} \mathrm{cm}^{-2}\right)$ & $614-634$ & $523-538$ & $567-578$ & $115-121$ & $89-102$ & $110-123$ \\
\hline Total dissolved solids $\left(\mathrm{mg} \mathrm{l}^{-1}\right)$ & $62.3-67$ & $53.3-55.9$ & $82-85.2$ & $40.3-43.6$ & $32.67-36$ & $42.3-46.3$ \\
\hline Current Velocity $\left(\mathrm{cms}^{-1}\right)$ & $15-19$ & $22-27$ & $18-21$ & $42-48$ & $46-51$ & $40-47$ \\
\hline Alkalinity $\left(\mathrm{mg} \mathrm{l}^{-1}\right)$ & $82.5-85$ & $82.6-84.4$ & $80.7-84$ & $53.5-55.5$ & $58-61$ & $51.2-54.2$ \\
\hline Hardness $\left(\mathrm{mg} \mathrm{l}^{-1}\right)$ & $189-195$ & $183-195$ & $190-198$ & $100-109$ & $130-142$ & $125-131$ \\
\hline Silicate $\left(\mathrm{mg} \mathrm{l}^{-1}\right)$ & $3.0-3.2$ & $3.2-3.6$ & $2.6-2.8$ & $3.0-3.2$ & $3.6-3.8$ & $2.6-3.0$ \\
\hline Phosphate $\left(\mathrm{mg} \mathrm{l}^{-1}\right)$ & $0.038-0.041$ & $0.049-0.052$ & $0.029-0.03$ & $0.04-0.041$ & $0.038-0.041$ & $0.029-0.031$ \\
\hline Nitrate $\left(\mathrm{mg} \mathrm{l}^{-1}\right)$ & $0.029-0.03$ & $0.04-0.042$ & $0.038-0.04$ & $0.03-0.029$ & $0.028-0.03$ & $0.048-0.05$ \\
\hline
\end{tabular}

Table 1. Range of Physico-chemical parameters in two locations during different seasons of Chandraprabha reservoir (S1) and its downstream (S2). 
The phytoplankton were represented by 74 taxa from 4 major groups namely Bacillariophyceae (43 genera), Chlorophyceae (19taxa), Cyanophyceae (9taxa) and Euglenophyceae (3taxa) at S1 and Bacillariophyceae (39genera), Chlorophyceae (18taxa), Cyanophyceae (7taxa) and Euglenophyceae (2taxa) at S2. The Bacillariophyceae members were found to be dominant throughout both the study sites. The densities varied from 584-1259 u/l at S1, while 245-829 u/1 at S2. Seasonal comparison shows that the total number of phytoplankton was low in rainy season compared with that of summer and winter (Table 2). The quantitative share exhibited similar trend with diatoms having largest share (least being $55.6 \%$ at $\mathrm{S} 1$ and $60.9 \%$ at $\mathrm{S} 2$ ), followed by green algae and others (Table 2). A total of 13 zooplankton taxa were identified from both the sites and represented by Rotifera, Cladocera, Copepoda and Protozoa. Zooplanktons densities varied from 243-889 u/l at S1 and 112$432 \mathrm{u} / 1$ at S2 and maximum in summer (Table 2). Qualitatively, the zooplankton consisted of Rotifers, (39\%), Cladocera and Protozoans (23\%), and Copepods (15\%) at S1 and Rotifers, (41\%), Cladocera and Protozoans (25\%), and Copepods $(8 \%)$ at $\mathrm{S} 2$, in order of richness. Quantitatively, also the order of abundance was similar. The quantitative share exhibited similar trend with Rotifers having largest share (least being $40 \%$ at $\mathrm{S} 1$ and $63.6 \%$ at S2), followed by Cladocera and others (Table 2).

\begin{tabular}{|c|c|c|c|c|c|c|}
\hline \multirow{2}{*}{$\begin{array}{l}\text { Sites } \\
\text { Parameters/Seasons }\end{array}$} & \multicolumn{3}{|c|}{ S 1} & \multicolumn{3}{|c|}{$\mathbf{S 2}$} \\
\hline & $\mathbf{S}$ & M & $\mathbf{W}$ & $\mathbf{S}$ & $\mathbf{M}$ & $\mathbf{W}$ \\
\hline Density of Zooplankton (u/l) & 889 & 243 & 568 & 432 & 112 & 253 \\
\hline Species Richness Zooplankton & 11 & 7 & 13 & 11 & 9 & 9 \\
\hline Density of Phytoplankton $(\mathrm{u} / \mathrm{l})$ & 1259 & 584 & 813 & 829 & 245 & 748 \\
\hline Species Richness of Phytoplankton & 63 & 53 & 61 & 52 & 49 & 54 \\
\hline Density of Macroinvertebrate (individuals $/ \mathrm{m}^{2}$ ) & 339 & 231 & 276 & 352 & 289 & 220 \\
\hline Species Richness of Macroinvertebrate & 7 & 5 & 7 & 8 & 8 & 4 \\
\hline \multicolumn{7}{|l|}{ Plankton composition } \\
\hline \multicolumn{7}{|l|}{ Phytopplankton } \\
\hline Bacillariophyceae & 55.6 & 58 & 56.8 & 61.9 & 60.9 & 66.6 \\
\hline Chlorophyceae & 27.5 & 30.8 & 30.5 & 31.6 & 31.7 & 27.1 \\
\hline Cyanophyceae & 14.5 & 8.79 & 10.1 & 6.01 & 6.86 & 5.52 \\
\hline Euglenophyceae & 2.46 & 2.47 & 2.58 & 0.52 & 0.57 & 0.83 \\
\hline \multicolumn{7}{|l|}{ Zoopplankton } \\
\hline Rotifera & 45.3 & 54 & 40 & 63.6 & 54.8 & 62.2 \\
\hline Cladocera & 24.4 & 20.6 & 23.8 & 9.09 & 21.4 & 13.3 \\
\hline Protozoa & 16.3 & 9.52 & 10 & 6.82 & 4.76 & 4.44 \\
\hline Copepoda & 14 & 15.9 & 26.3 & 20.5 & 19 & 20 \\
\hline \multicolumn{7}{|l|}{ Macroinvertebrate composition } \\
\hline Gastropoda & 29.7 & 37.5 & 28.6 & 23.3 & 34.3 & 45 \\
\hline Trichoptera & 13.5 & 16.7 & 14.3 & 20 & 14.3 & 15 \\
\hline Ephemeroptera & 10.8 & 20.8 & 10.7 & 13.3 & 14.3 & 20 \\
\hline Diptera & 32.4 & 12.5 & 39.3 & 26.7 & 25.67 & 20 \\
\hline Chironomids & 21.6 & 0 & 25 & 16.7 & 8.57 & 0 \\
\hline Other Diptera & 10.8 & 12.5 & 14.3 & 10 & 17.1 & 20 \\
\hline Coleoptera & 8.11 & 12.5 & 3.57 & 6.67 & 5.71 & 0 \\
\hline Odonata & 5.41 & 0 & 3.57 & 6.67 & 2.86 & 0 \\
\hline Hemiptera & 0 & 0 & 0 & 3.33 & 2.86 & 0 \\
\hline
\end{tabular}

Table: 2. Density, species richness and \% share of Biota at Chandraprabha reservoir and its downstream. 
During the study, macro-invertebrate fauna was represented by Orders Diptera, Coleoptera, Gastropoda, Odonata, Hemiptera, Trichoptera and Ephemeroptera at both the sites (Table 2). Of these Hemiptera was absent at S2. Diptera, mostly represented by larvae of different mosquitoes and Chironomid flies were abundant, followed by Gastropoda at S1 while Diptera and Gastropods were highest in percentage at S2. The densities of macro-invertebrates ranged from 231-319 individuals $/ \mathrm{m} 2$ at the reservoir (S1) while 220352 individuals $/ \mathrm{m} 2$ at downstream $\mathrm{S} 2$. The density in general was highest during summer at S1 while during winter at S2 (Table 2).

\section{Discussion}

Wetlands are probably the earth's most important fresh water resource of earth and are the most threatened too. The present study examines Chandraprabha sanctuary in light of its PA tag. Sediment quality indicated that both the sites were sandy loam in nature. Water quality parameters such as current velocity, $\mathrm{pH}$, dissolved oxygen, total alkalinity and total hardness differed at S1 and S2. CV and DO was low in the reservoirs compared with fluvial downstream station (S2) while reservoir (S1) was rich in bicarbonate ions. Among phytoplankton, Bacillariophyta was dominant followed by Chlorophyta and Cyanophyta at both the sites. It is a wellestablished fact that plankton is used to compare the relative productivity and fishery potential of different water bodies [Jhingran 1991]. Among phytoplankton at S1 was slightly richer in diatoms and green algae populations, but qualitatively more diatoms followed by green algae occurred at S2. In general, the requirement of dissolved oxygen for growth of many diatom species is well documented. In the present study, the river water showed higher population of diatoms which coincided with the higher dissolved oxygen throughout the study period. The Diatoms choose well aerated waters that are rich in dissolved oxygen, which support the present observation [Ramesha and Sophia 2013; Venkateshwarlu 1970]. Moreover the water from catchment area surface runoff brings nutrients that enriched the reservoir during monsoon, and result in higher values of plankton during summer. The density of phytoplankton has earlier been recorded to be greater during summer (629-759 u/l) and winter (348-413 u/l) and lowest in monsoon in Gobindsagar Reservoir [Kumar 1990; Singh et. al. 2010; Nautiyal 1996; Patil Alaka 2015]. Findings of present investigation stand clearly in support of these earlier observations.

Among zooplankton rotifers were dominant at S2, while cladocera and copepod dominated the scenario at reservoir. The macroinvertebrate composition varied only mildly. In general, increased nutrient levels and phytoplankton density lead to the increases in zooplankton abundance [Lin et. al. 2003]. 7 species of Rotifers have been identified that comprise $40.33 \%$ among the zooplankton groups. In Deccan wetlands the rotifers formed the most dominant zooplankters with higher density. Minimum density of zooplankton was recorded in rainy season, maximum during winter and summer in Vadgaon tank of Kolhapur (Maharastra) also. Species richness was less in case of macroinvertebrates when compared to plankton because of the response of former to poor habitat quality. It has been reported that less habitat-dependency of plankton when compared with macroinvertebrates consents to more occupancy of plankton on several habitats [Manjare et. al. 2010; Chandrasekhar 2007; McCormick and Cairns 1994). However, the share of Chironomidae was high only in the Reservior site (S1) attributed to presence of soft substratum (sand), as also observed at rocky mountain drainage system [Knight and Gaufin 1966; Nautiyal et. al. 2013]. Temporarily there was no difference in most abundant taxa in S1 and S2 except abundance of Chironomidae in S1 during summer and winter. There was a gradual decrease in the total number of plankton as the water progressed downstream. Specific conductivity, TDS, CV, and DO accounted for variations in plankton richness and density in the reservoir and it's downstream. 
Diatoms were predominant at all seasons. Their number followed by green algae was more in fluvial stretch (Site S2). Among zooplankton rotifers occurred in great numbers at S2, while number of cladocera and copepods were greater at S1. The benthic macroinvertebrates community differed slightly at S1 and S2.

\section{Conclusion}

The present piece of work is a preliminary investigation on protected area of Chandraprabha sanctuary. It can be assumed on the basis of present investigation that Chandraprabha reservior is a rich site for the growth of biota and therefore is a potential site for conservation and development of various aquatic flora and fauna. Reservoirs are also a more reliable source of water supply for irrigation, domestic and industrial use. The reservoirs directly support many activities including fisheries, navigation, and recreation. Higher biotic diversity observed in reservoir site (S1) may be due to the higher nutrient enrichment and the lentic nature of the habitat. The reservoir was observed to be the most suitable habitat for the growth of periphytic microalgae characterized by the abundance and diversity.

\section{Acknowledgments}

One of the authors (JV) is grateful to UGC-New Delhi providing for financial assistance to her Women Postdoctoral Fellowship Program. The thanks are also due to the head, Department of Zoology, University of Allahabad for providing facilities to carry this work.

\section{References}

Anonymous (2007): Report of the Task Force on Islands, Coral Reefs, Mangroves and Wetlands. In Environment \& Forests, 7387.

APHA, AWWA, WPCF and WEF (1998): American Public Health Association, American Water Works Association, Water Pollution Control Federation and Water Environment Federation "Standard
Methods for the Examination of Water and Wastewater", 20th edn. American Public Health Association, Washington DC.

Chandrasekhar, S. V. A. (2007): Physicochemical characteristics and zooplankton of Hussainsagar Lake, Hyderabad. Rec. Zool. surv. India 107(2): 51-59.

Corkum, L. D. (1989): Patterns of benthic invertebrate assemblages in rivers of northwestern North America. Freshwat. Biol., 21: 191-205.

Cowardin, L. M.; Carter, V.; Golet, F. C. and LaRoe, E. T. (1979): Classification of wetlands and deepwater habitats of the United States. U.S. Department of the Interior, Fish and Wildlife Service, Washington, D.C. 131

Edmondson, W. T. (1959): Rotifers, p. 420-494. In: W.T. Edmondson (ed.) Fresh-water Biology, 2nd Ed., Wiley, New York, 1248.

Jhingran, V. G. (1991): Fish and Fisheries of India, 3rd ed. Hindustan Publishing Corporation, Delhi, India, 727.

Knight, A. W. and Gaufin, A. R. (1966): Altitudinal distribution of stoneflies (Plecoptera) in a rocky mountain drainage system. J. Kansas Entomol. Soc., 39: 668675.

Kumar, K. (1990): Management and Development of Gobindsagar Reservoir. A Case Study, Proc. Nat. Workshop Reservoir Fish, 13-20.

Lin, Q. Q.; Hu, R. and Duan, S. S. (2003): Reservoir trophic states and the response of plankton in Guangdong Province. Acta Ecol 23(6): 1101-1108

Macan, T. T. (1979): A key to nymphs of the British species Ephemeroptera with notes 
on their ecology, 3rd edn. Freshwater Biological Association, Ambleside.

Manatunge, J. and Priyadarshana, T. (2006): Environmental and social impacts of reservoirs: issues and mitigation oceans and aquatic ecosystems - 1 Environmental and Social Impacts of Reservoirs: Issues and Mitigation- J. Manatunge, M. Nakayama and T. Priyadarshana Encyclopedia of Life Support Systems (EOLSS).

Manjare, S. A.; Vhanalakar, S. A. and Muley, D. V. (2010): "Water Quality Assesment of Vadgaon tank of Kolhapur (Maharastra), with Special Reference to Zooplankton" International J. Ad. Bio. Res. 1(2): 91-95

Matta, G. (2014): "A study on physico-chemical Characteristics to assess the pollution status of river Ganga in Uttarakhand." Journal of Chemical and Pharmaceutical Sciences, 7(3): 210-217.

Matta, G. and Kumar, A. (2015): Monitoring and Evaluation of River Ganga System in Himalayan Region with Reference to Limnological Aspects. World Applied Sciences Journal, 33 (2): 203-212.

Matta, G. and Kumar, A. (2017): Health Risk, Water Hygiene, Science and Communication. ESSENCE Int. J. Env. Conser. Rehab, 8(1): 179 - 186.

Matta, G. and Laura, G. (2016): Mercury, lead and arsenic: impact on environment and human health India. Journal of Chemical and Pharmaceutical Sciences, 9(2): 718 725 .

Matta, G.; Bhadauriya, G. and Singh, V. (2011): Biodiversity and Sustainable Development: A Review. ESSENCE - Int $\mathrm{J}$ for Env Rehab and Conser, 2(1): $72-$ 80.
Matta, G.; Laura, G.; Kumar, A. and Machel, J. (2018): Hydrochemical characteristics and planktonic composition assessment of River Henwal in Himalayan Region of Uttarakhand using CPI, Simpson's and Shannon-Weaver Index. Journal of Chemical and Pharmaceutical Sciences, 11(1).

McCormick, P. V. and Jr. Cairns, J. (1994): Algae as indicators of environmental change. J. App. Phyco. 6: 509-526.

Mitsch, W. J. and Gosselink, J. G. (2000): Wetlands, John Wiley and Sons, Inc. New York, 31 .

Nautiyal, P. (1996): The River Valley Project in Garhwal region: Impact on the Population Dynamics of Endangered Himalayan Mahseer with Emphasis on Bioconservation. Final technical report submitted to Ganga Project Directorate, Ministry of Environment and Forests Government of India, New Delhi (J 11013/8/92-GDP/24.09.92), 96.

Nautiyal, P.; Mishra, A. S. and Singh, K. R. (2013): Benthic macroinvertebrate fauna in the headwaters of Doon Valley streams, India. Journal of the Kalash Science, 2(1): 1-10.

Needham, J. G. and Needham, P. R. (1975): A Guide to the Study of Fresh Water Biology. 5th edition Holden Day Ins, 108 San-Francisco, USA.

Nwankwo, D. I. (2004): A Practical Guide to the study of Algae. JAS Publishers, Lagos, Nigeria.

Patil, A. A. (2015): Biodiversity of Bhambarde Reservoir of Sangli, Maharashtra, India. Research Journal of Recent Sciences, 4: 209-215. 
Pennak, R. W. (1953): Fresh-water Invertebrates of the United States. Ronald Press Co., New York, 769.

Ramesha, M. M. and Sophia, S. (2013): Species composition and diversity of plankton in the River Seeta at Seetanadi, the Western Ghats, India. Advanced Bio Tec. 12(81).

Singh, M.; Lodha, P. and Singh, G. P. (2010): Seasonal Diatom Variations with Reference to Physico-chemical Properties of Water of Mansagar Lake of Jaipur, Rajasthan. Research Journal of Agricultural Sciences, 1(4): 451-457.

Smith, R. I. (1980): Ecology and Field Biology; (3rd edition) Harper and Row, New York.

Venkateshwarlu, V. (1970). An ecological study of the algae of the river Moosi special reference to water pollution IV. Periodicity of some common species of algae, Hydrobiol 35(1): 45.

Welch (1948): Limnological methods. Blakiston, Philadelphia, 381. 